\title{
The Impact of the Block Freeze Concentration Process on Human Milk Properties Intended for Feeding Newborns
}

\author{
Ana Claudia Berenhauser ${ }^{1}$, Maria Helena Machado Canella², Isabella de Bona Muñoz ${ }^{2}$, \\ Elane Schwinden Prudencio², J. Vladimir Oliveira ${ }^{3}$, Jane Mara Block ${ }^{2}$ \\ ${ }^{1}$ Maternity Ward of UFSC, UFSC, Florianópolis, Brazil \\ ${ }^{2}$ Department of Food Science and Technology, UFSC, Florianópolis, Brazil \\ ${ }^{3}$ Department of Chemical and Food Engineering, UFSC, Florianópolis, Brazil \\ Email: anacberenhauser@yahoo.com.br
}

How to cite this paper: Berenhauser, A.C., Canella, M.H.M., de Bona Muñoz, I., Prudencio, E.S., Oliveira, J.V. and Block, J.M. (2017) The Impact of the Block Freeze Concentration Process on Human Milk Properties Intended for Feeding Newborns. Food and Nutrition Sciences, 8, 402-418.

https://doi.org/10.4236/fns.2017.84028

Received: March 8, 2017

Accepted: April 24, 2017

Published: April 27, 2017

Copyright $\odot 2017$ by authors and Scientific Research Publishing Inc. This work is licensed under the Creative Commons Attribution International License (CC BY 4.0).

http://creativecommons.org/licenses/by/4.0/ (c) (i) Open Access

\begin{abstract}
Human milk is the ideal nutritional support for premature neonates. Considering the need for aggregating nutritional value to human milk provided to such vulnerable group of infants, human milk was concentrated by the block freeze concentration technique. The effects of freeze concentration on the physicochemical properties, the efficiency of the process, color parameters, and the density and dynamic viscosity of human milk were assessed. The freeze concentration technology was used to successfully concentrate human milk to a factor equal to $180.48 \%$ and $72 \%$ of total solid retention in the second stage of freeze concentration. The values observed in the concentrates for the biochemical properties showed that the fraction of concentrated fluid human milk of the second stage (C2) presented elevated amounts of carbohydrates, protein and energy. The elevated caloric value observed in the ice fraction of the first stage (I1) refers to the retention of lipids in it. When added to human milk, C2 and I1 may satisfy the special requisites of nutrients and energy to guarantee the growth and development of preterm neonates.
\end{abstract}

\section{Keywords}

Freeze Concentration, Human Milk, Human Milk Fortifier, Premature Neonate

\section{Introduction}

Human milk is the ideal nutritional support for premature neonates and its use is encouraged at the neonatal intensive care units and after the premature baby goes home [1]. However, the mothers of such premature babies are less inclined to begin expressing milk, sustain lactation and provide their milk soon after 
birth. Thus, it is recommended that milk from human milk banks is used to provide an exclusive and appropriate diet during the first weeks of life of the baby [2]. Nevertheless, human milk donors are usually mothers of full-term babies and the milk produced by them has a composition that differs from the milk of mothers of preterm babies, i.e., usually contain less protein and lipids. Moreover, premature neonates need higher caloric intake as compared to full-term newborns [3].

Halleux et al. [2] and Oliveira et al. [4] reported that preterm newborns are even more vulnerable and immature than full-term newborns of the same postnatal age, presenting higher gastric $\mathrm{pH}$, lower enzymatic activities, faster gastric emptying, and lower concentrations of electrolytes in their digestive fluids, among other limitations. Grance et al. [5] and Lönnerdal [6] emphasize that one of the ways of supplementing human milk for preterm babies would be to add proteins of bovine origin. On the other hand, Errázuriz et al. [7] state that cow's milk proteins are the antigens that most frequently cause sensitivity in infants. Milk protein allergy in neonates can manifest as digestive, skin and respiratory problems [7], in addition to a deficiency in growth rate [8], and the appearance of the illness named necrotizing enterocolitis [9]. Sullivan et al. [10], and Schanler [9], report that making use of a diet based on quality human milk can reduce, or even eliminate, the development of enterocolitis.

A few human milk based supplements are available on the Market, but their elevated costs may limit their use [3] [11]. Such supplements may be also obtained by submitting human milk to expensive industrial technologies, such as centrifugation [11], evaporation [12], and freeze dry [5]. Despite high-level similarities between human milk and infant formulas, a closer inspection indicates a number of important differences, which may underlie the known nutritional and functional differences between these two sources of infant nutrition [13]. An innovating alternative that aims at supplementing human milk is the concentration of the total solids of such raw material by applying the freeze concentration process. Belén et al. [14] reported that this process promotes the concentration of the liquid food products by freezing and subsequently separating a part of the frozen water.

Freeze concentration is considered a phenomenon that occurs during thawing of a solution resulting in a concentrated phase and another in the form of ice [14] [15]. This process has a few advantages, such as a low chemical deterioration due to decreased enzymatic and microbiological activity and almost no loss of volatile components of the raw material [16]. Hence, freeze concentration is a process able to guarantee a higher quality of the product submitted to it [17], providing a more selective water removal [18], in addition to being simple and having lower costs when compared to other industrial techniques. Adding the phases obtained through freeze concentration may increase the nutritive properties of human milk, since that feature is attributed to the low temperatures employed, which avoid the degradation of its components. Thus, using freeze concentration in liquid foods enables the obtainment of products with higher nutritional and sensorial quality, in addition to avoiding undesirable chemical and 
biochemical changes [17] [19] [20]. In order to improve the efficiency of the process, Aider and Halleux [17] and Chabarov and Aider [21] indicate that is necessary to know the impact of the behavior on the raw material, in our case on human milk, to be submitted to this process considered as an emerging one; thus forecasting the future conditions that will be necessary for applying such technique. There are no reports in the literature on the effect of block freeze concentration on the human milk. The objective of the present study was to evaluate the effect of block freeze concentration on the physicochemical properties and freeze concentration performance on the human milk aiming the utilization of the concentrated fractions in newborn feeding.

\section{Material and Methods}

\subsection{Human Milk Sampling}

This study was approved by the Ethics Committee of the Federal University of Santa Catarina. In this study was used human milk samples from 8 donors aged between 21 and 36 years old, between May to July, 2016, as follows: donor 1 (21 years old, 3 weeks of breast feed time); donor 2 (23 years old, 3 weeks of breast feed time); donor 3 (23 years old, 2 weeks of breast feed time); donor 4 (24 years old, 3 weeks of breast feed time); donor 5 ( 28 years old, 2 weeks of breast feed time); donor 6 ( 29 years old, 4 weeks of breast feed time); donor 7 (32 years old, 5 weeks of breast feed time); donor 8 (36 years old, 3 weeks of breast feed time).All donors were mothers of full-term babies, who met the criteria established by the Operating Manual for Human Milk Banks [22] for the donation of human milk. The human milk samples from Human Milk Bank of Motherhood Carmela Dutra, Childrens Hospital Joana de Gusmão (Florianópolis, Santa Catarina, Brazil) and Regional Hospital of São José (São José, Santa Catarina, Brazil) were collected manually into sterilized glass jars following the hygiene guidelines outlined in the Operating Manual for Human Milk Banks [22]. Each one human milk sample was submitted to LTLT (low temperature long time) pasteurization, pooled and shaken with vortex turbulence.

\subsection{Freeze Concentration Procedure}

The freeze concentration methodology applied to the human milk was the block freeze concentration, described by Boaventura et al. [23]. The method is based on total freezing of human milk followed by a partial defrosting procedure under simple gravitational separation. This method makes it possible to obtain two fractions denoted as concentrated fluid human milk (C) and ice (I) (Figure 1). An initial weight of $3.48 \mathrm{~kg}$ of human milk was divided into three batches of 1.16 $\mathrm{kg}$ and then frozen at $-20^{\circ} \mathrm{C} \pm 2^{\circ} \mathrm{C}$ in a freezer unit (Electrolux, FE 18, São Carlos, Brazil) by indirect cooling. Once the human was frozen, $50 \%$ of the initial weight was defrosted at room temperature $\left(20^{\circ} \mathrm{C} \pm 2^{\circ} \mathrm{C}\right)$. The total defrosted liquid obtained $(1.74 \mathrm{~kg})$ was the concentrated fluid human milk of the first freeze concentration stage $(\mathrm{C} 1) . \mathrm{C} 1$ was also frozen at $-20^{\circ} \mathrm{C} \pm 2^{\circ} \mathrm{C}$ and defrosted $\left(20^{\circ} \mathrm{C} \pm 2^{\circ} \mathrm{C}\right)$ up to $50 \%$ of the weight $(0.87 \mathrm{~kg})$ and it was the concentrated fluid 


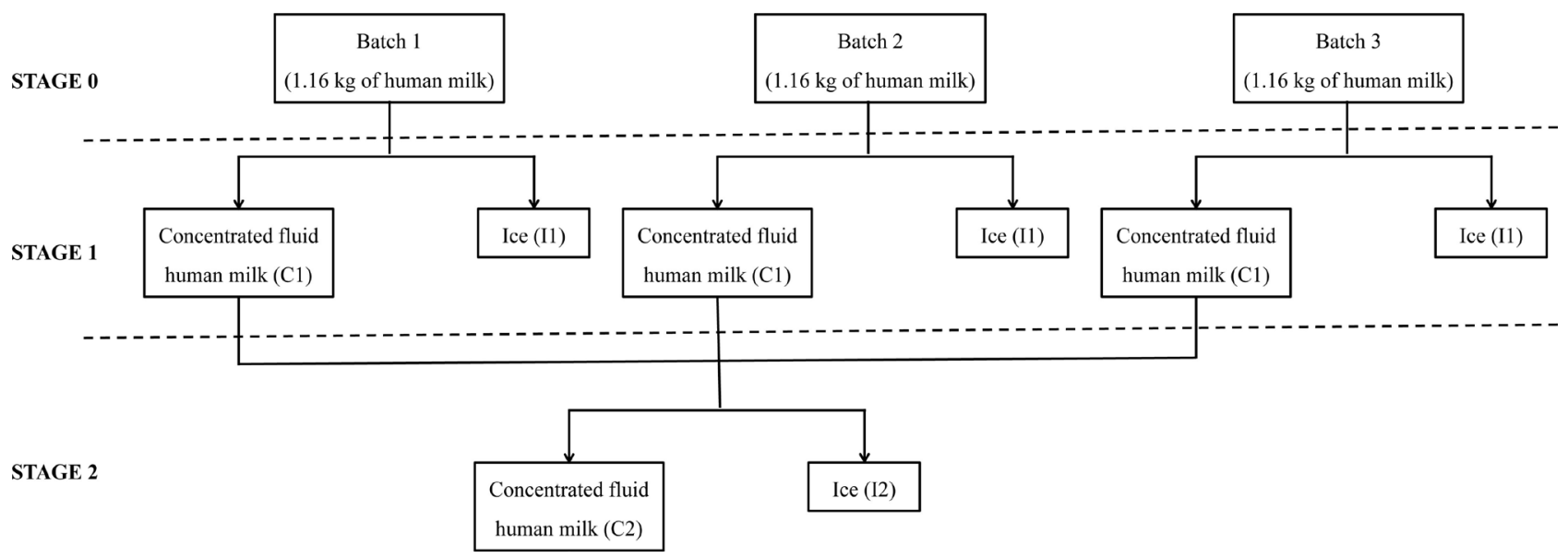

Figure 1. Human milk concentration using the block freeze concentration process.

human milk of the second freeze concentration stage (C2). The human milk, ices (I1 and I2) defrosted remaining from each freeze concentration stage and an aliquot of each concentrated fluid milk human (C1 and C2) were evaluated in relation to physicochemical properties, freeze concentration performance, color parameters, density and dynamic viscosity.

\subsection{Physicochemical Analysis}

The titratable acidity ( $\mathrm{g} / 100 \mathrm{~g}$ lactic acid) was determined according to Instituto Adolfo Lutz (IAL) methodology [24], while the $\mathrm{pH}$ values were measured using a pH meter $( \pm 0.01)$ (PHS-3 BW, BEL, Piracicaba, São Paulo, Brazil).

Total solids content $(\mathrm{g} / 100 \mathrm{~g})$ was determined by drying of the samples to constant weight at $70^{\circ} \mathrm{C}$ under vacuum condition for 24 hours. Protein was estimated by measuring the $N$ content of samples by the Kjeldahl method and multiplying by a conversion factor equal to 6.38 . The lipid content was determined according to Gerber method, while the ash content was obtained by gravimetric method. These analytical procedures followed the appropriate standard methods [25]. The value for total carbohydrate was determined by difference. The caloric value $(\mathrm{kcal} / \mathrm{g})$ was calculated from the conversion factors, which were equal to 4 $\mathrm{kcal} / \mathrm{g}, 9 \mathrm{kcal} / \mathrm{g}$ and $4 \mathrm{kcal} / \mathrm{g}$ for protein, lipid and carbohydrates, respectively. All analyses were carried out in triplicate. The chemicals used were of analytical grade and when necessary the solutions were properly prepared and standardized.

\subsection{Freeze Concentration Performance}

The concentration factor at each freeze concentration stage was calculated as a function of the increase of the concentration of the solution in relation to the total solids content (TS) [26]. The concentration factor was obtained as described in Equation (1):

$$
\mathrm{CF}(\%)=\frac{\mathrm{TS}_{n}}{\mathrm{TS}_{0}} \times 100
$$

where $\mathrm{CF}$ is the concentration factor $(\%), \mathrm{TS}_{n}$ is the total solid content $(\mathrm{g} / 100 \mathrm{~g})$ 
at a given freeze concentration stage $(n=1$ or 2$)$ and $T S_{0}$ is the total solid content $(\mathrm{g} / 100 \mathrm{~g})$ of the human milk.

The process efficiency of the freeze concentration process was determined according to Belén et al. [27], based on the total solids contents (g/100g). Thus, the process efficiency (PE) (\%) of the freeze concentration was determined by the increase of TS in the human milk concentrated fluid $(\mathrm{C})(\mathrm{g} / 100 \mathrm{~g})$ in relation to the TS remaining in ices $\mathrm{I}(\mathrm{g} / 100 \mathrm{~g})$ defrosted from each freeze concentration stage $(n)$, as described in the Equation (2):

$$
\operatorname{PE}(\%)=\frac{\text { TS in the } C_{n}-\text { TS in the } I_{n}}{\text { TS in the } C_{n}} \times 100
$$

As recommended by Petzold et al. [28], to validate the obtained experimental results, a mass balance of each freeze concentration stage was made and compared to the theoretical value. The mass balance was calculated for each freeze concentration stage from the results obtained for the total solids content (TS) of human milk, concentrated fluid human milk (C1 and C2) and ice (I1 and I2). The mass balance of the first stage of freeze concentration (C1) was calculated in relation to TS of the human milk and the second stage (C2) in relation to TS of C1.

\subsection{Color Analysis}

The color analysis of the human milk, concentrated fluid human milk (C1 and C2) and ice (I1 and I2) defrosted samples was determined using a colorimeter Minolta Chroma Meter CR-400 (Konica Minolta, Osaka, Japan), adjusted to operate with D65 lightning and $10^{\circ}$ of observation angle. The colorimeter was calibrated with a white standard plate and to measure the $L^{*}, b^{*}$ and $a^{*}$ parameters was used the CIELab color scale. The $L^{*}$ parameter ranges 0 to 100 and indicates luminosity (variation from black to white), the $b^{*}$ axis is the variation from yellow $\left(+b^{\star}\right)$ to blue $\left(-b^{\star}\right)$ and the $a^{*}$ axis shows the variation from red $\left(+a^{*}\right)$ to green $\left(-a^{*}\right)$. The value of Hue angle $\left(h^{\star}\right)$ and Chroma $\left(C^{\star}\right)$ were determined using Equation (3) and Equation (4), respectively [29]. All analyses were done four times.

$$
\begin{gathered}
h^{*}=\tan ^{-1}\left(b^{*} / a^{*}\right) \\
C^{*}=\sqrt{\left(a^{*}\right)^{2}+\left(b^{*}\right)^{2}}
\end{gathered}
$$

\subsection{Density}

The density of the human milk, concentrated fluid human milk (C1 and C2) and ice (I1 and I2) defrosted was determinate by methodology described by AOAC [25]. A glass pycnometer (Gay-Lussac's pycnometer) (previously equilibrated to constant weight at $25^{\circ} \mathrm{C}$ ) was used. The density $\left(\mathrm{g} / \mathrm{cm}^{3}\right)$ realized in triplicate was calculated using the following Equation (5):

$$
\rho_{S}=\frac{(m 3-m 1)}{(m 2-m 1) \times \rho \mathrm{H}_{2} \mathrm{O}}
$$


where $\rho_{S}$ is the density of solutions $\left(\mathrm{g} / \mathrm{cm}^{3}\right), m 1$ is the mass of empty pycnometer $(\mathrm{g}), \mathrm{m} 2$ is the mass of pycnometer with water $(\mathrm{g}), \mathrm{m} 3$ is the mass of pycnometer with solutions ( $\mathrm{g}$ ), and $\rho \mathrm{H}_{2} \mathrm{O}$ is the density of water.

\subsection{Dynamic Viscosity}

The dynamic viscosity was measured using Falling-Ball Viscometer based on the measuring principle by Hoeppler (VEB MLW, Lesskestrabe, Germany), as described by Palczewska-Tulinska and Oracz [30], with modifications. In this viscometer is employed the rolling-ball principle, which it uses gravity as the driving force. A ball rolls through a closed capillary filled with sample fluid which is inclined at $10^{\circ}$ angle with vertical axis. The time it takes the ball to travel a defined measuring distance is a measure for the fluid's viscosity. Thus, the inclination angle of the capillary permits the user to vary the driving force. For calculating the viscosity from the measured time, the fluid's density obtained for human milk, C1, C2, I1 and I2 were used. The ball $N^{\circ} 2$ with mass of $4.459 \mathrm{~g}$ and density equal to $2.228 \mathrm{~g} / \mathrm{cm}^{3}$ was necessary to obtain the viscosity values. A liquid bath thermostat was responsible to maintain the temperature control at $35^{\circ} \mathrm{C}$ $\pm 1^{\circ} \mathrm{C}$, because it is the human milk temperature during the breastfeeding. The reading was done manually by the operator and calculated in triplicate using the following Equation (6).

$$
\eta=t \times\left(\rho_{b}-\rho_{s}\right) \times K
$$

where $\eta$ is dynamics viscosity (mPas), $t$ is ball rolling time (s), $\rho_{b}$ is ball density $\left(\mathrm{g} / \mathrm{cm}^{3}\right), \rho_{s}$ is sample density $\left(\mathrm{g} / \mathrm{cm}^{3}\right)$ and $K$ is proportionality constant.

\subsection{Statistical Analyses}

The data were expressed as means and standard deviation. The significance of the differences between the means of the milk samples was determined by analysis of variance (ANOVA) followed by Tukey's studentized range (5\% of significance). All statistical analyses were performed using the software STATISTICA version 12.0 (StatSoft Inc., Tulsa, OK, USA).

\section{Results and Discussion}

Figure 2 and Figure 3 show the titratable acidity and $\mathrm{pH}$, respectively, from each freeze concentration stage for human milk, concentrated fluid human milk fractions ( $\mathrm{C} 1$ and $\mathrm{C} 2)$ and ice fractions (I1, I2). No differences $(P>0.05)$ were found between human milk, $\mathrm{C} 1$ and $\mathrm{C} 2$ acidity values; nevertheless, they were lower $(P<0.05)$ for ice fractions $(\mathrm{I} 1, \mathrm{I} 2)$. All results were in accordance with the National Health Surveillance Agency of Brazil which classifies the range of 1.0 $8.0^{\circ} \mathrm{D}(0.01 \mathrm{~g} / 100 \mathrm{~g}$ and $0.08 \mathrm{~g} / 100 \mathrm{~g}$, respectively) as an adequate acidity [22]. However, bacteria that integrate normal human milk microbiota can ferment lactose, resulting in an increase in lactic acid and in an elevation of its acidity. Pereira et al. [31], reported that high and low values for human acidity may in- 


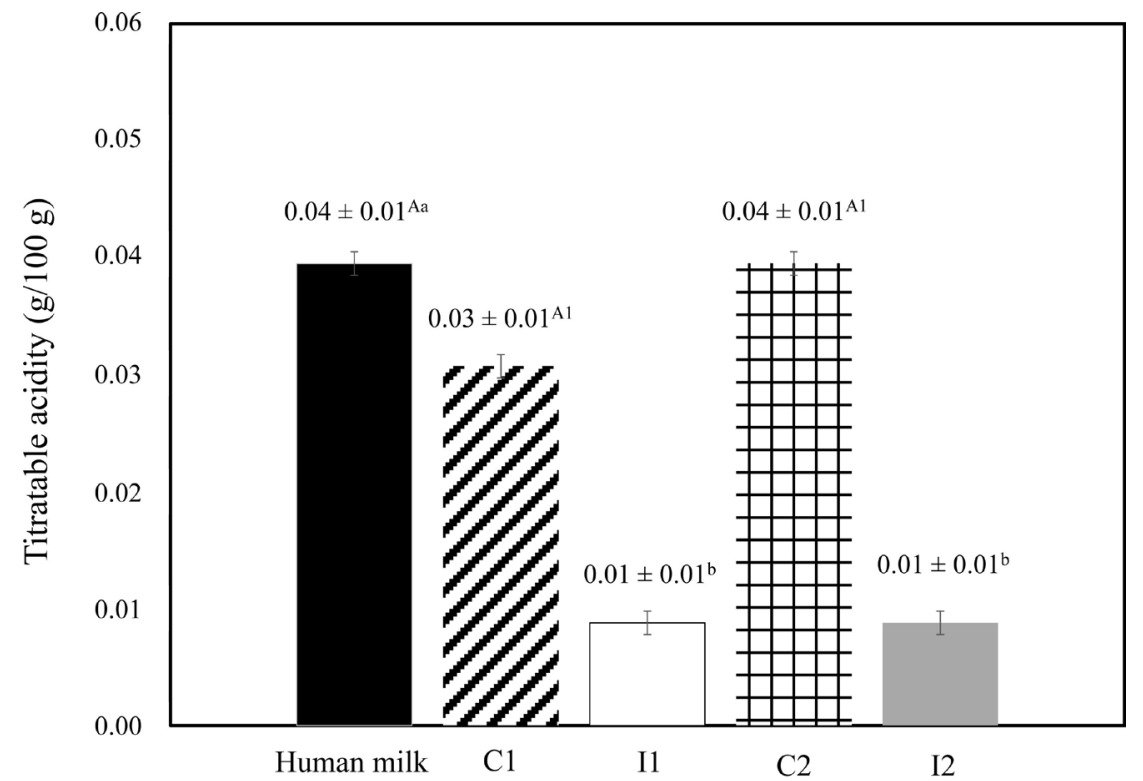

Results are expressed as mean \pm standard deviation, among three batches carried out in triplicate for each freeze concentration stage, with three repetitions for titratable acidity. ${ }^{\mathrm{A}-\mathrm{C}}$ Different superscript uppercase letters denote significant differences $(P<0.05)$ between the human milk and the $C$ of each freeze concentration stage. ${ }^{\text {a-c }}$ Different superscript lowercase letters denote significant differences $(P$ $<0.05)$ between the human milk and the $I$ of each freeze concentration stage. ${ }^{1-2}$ Different superscript numbers denote significant differences $(P<0.05)$ between the $C$ of each freeze concentration stage.

Figure 2. Titratable acidity (g/100g) of the human milk, concentrated fluid human milk $(C)$ and ice $(I)$ for the two freeze concentration stages.

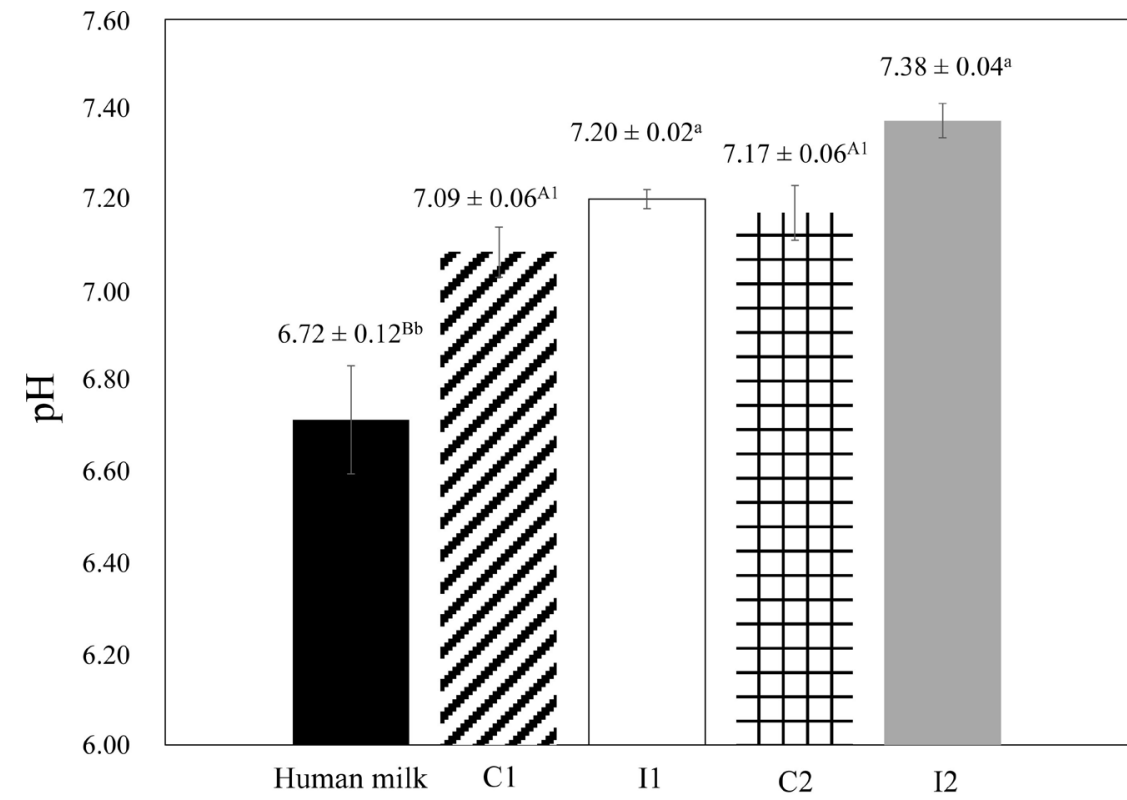

Results are expressed as mean \pm standard deviation, among three batches carried out in triplicate for each freeze concentration stage, with three repetitions for $\mathrm{pH}$ values. ${ }^{\mathrm{A}-\mathrm{C}}$ Different superscript uppercase letters denote significant differences $(P<0.05)$ between the human milk and the $C$ of each freeze concentration stage. ${ }^{\text {a-c }}$ Different superscript lowercase letters denote significant differences $(P<0.05)$ between the human milk and the I of each freeze concentration stage. ${ }^{1-2}$ Different superscript numbers denote significant differences $(P<0.05)$ between the $C$ of each freeze concentration stage.

Figure 3. $\mathrm{pH}$ values of the human milk, concentrated fluid human milk $(C)$ and ice $(I)$ for the two freeze concentration stages. 
fluence the biological availability of nutrients, such as calcium, which is essential for bone mineralization in preterm infants. Therefore, considering the importance of human milk acidity for its nutritional quality, it should be emphasized that acidic or alkaline overloads result in metabolic acidosis or alkalosis, and its use can cause necrotizing enterocolitis in very low birth weight preterm infants [31].

Regarding the $\mathrm{pH}$ results, no differences $(P<0.05)$ were observed between $\mathrm{C} 1$ and C2 samples, and I1 and I2 samples, respectively. However, when these values were compared with human milk, it was possible to note that lower value ( $P$ $<0.05)$ was obtained for the human milk. According to Cavalcante et al. [32], those values may vary between 5.47 and 7.84 and depend on the week of lactation and the lipids present. The same authors affirm that human milk can be considered as food that is initially little basic, becoming slightly acidic (up to the $21^{\text {st }}$ day after birth) and then stabilizing between neutral and slightly basic (up to 180 days after birth). In light of the foregoing, the results observed for $\mathrm{pH}$ in this study are within the acceptable parameters.

The results referring to the total solids contents, the concentration factor (CF) and process efficiency $(\mathrm{PE})$ are shown in Table 1 . These results show that it was possible to concentrate the total solids of human milk, and the CF and PE values obtained were higher $(P<0.05)$ in the second than in the first freeze concentration stage. During the freeze concentration of whey, Aider and Ounis [26] observed that both values, $\mathrm{CF}$ and $\mathrm{PE}$, were directly dependent on the total solids content. When concentrating the whey of fresh cheddar cheese [33], the authors mentioned that the elevated content of free water present in the first two stages of concentration was responsible for the greater efficiency of the process. Sánchez et al. [34] and Aider and Ounis [26] associated a decrease in the effectiveness of the process with an increase in the viscosity of the solution obtained after increasing dry matter contents and the retention of solids in the ice fraction during the freeze concentration process.

Table 1. Total solids content of the human milk, concentrated fluid human milk the mass transfer in relation to total solids content for the two freeze concentration stages.

\begin{tabular}{|c|c|c|c|c|}
\hline & & Total solids (g/100g) & $\mathrm{CF}(\%)$ & $\mathrm{PE}(\%)$ \\
\hline Human milk & & $11.95 \pm 0.11^{\mathrm{Ca}}$ & - & - \\
\hline \multirow[t]{2}{*}{ Stage 1} & $\mathrm{C} 1$ & $14.17 \pm 0.01^{\mathrm{B} 2}$ & $118.59 \pm 1.06^{\star}$ & $43.88 \pm 0.82^{*}$ \\
\hline & $\mathrm{I} 1$ & $7.95 \pm 0.12^{\mathrm{b}}$ & - & - \\
\hline \multirow[t]{2}{*}{ Stage 2} & $\mathrm{C} 2$ & $21.57 \pm 0.17^{\mathrm{A} 1}$ & $180.48 \pm 0.27^{+}$ & $70.30 \pm 0.2^{+}$ \\
\hline & $\mathrm{I} 2$ & $6.41 \pm 0.09^{c}$ & - & - \\
\hline
\end{tabular}

Results are expressed as mean \pm standard deviation, among three batches carried out in triplicate for each freeze concentration stage, with three repetitions for total solids content, CF and PE. ${ }^{\mathrm{A}-\mathrm{D}} \mathrm{Within}$ a column, different superscript uppercase letters denote significant differences $(P<0.05)$ between the human milk and the $C$ of each freeze concentration stage. ${ }^{\mathrm{a}-\mathrm{d}}$ Within a column, different superscript lowercase letters denote significant differences $(P<0.05)$ between the human milk and the I of each freeze concentration stage. ${ }^{1-3}$ Within a column, different superscript numbers denote significant differences $(P<0.05)$ between the $C$ of each freeze concentration stage. Different symbols indicate significant differences $(P<0.05)$ in the $\mathrm{CF}$ and $\mathrm{PE}$ of each freeze concentration stage. 
Table 2. Physicochemical properties of the human milk, concentrated fluid human milk $(C)$ and ice $(I)$ for the two freeze concentration stages.

\begin{tabular}{ccccccc}
\hline & & $\begin{array}{c}\text { Protein } \\
(\mathrm{g} / 100 \mathrm{~g})\end{array}$ & Lipid (g/100g) & Ash $(\mathrm{g} / 100 \mathrm{~g})$ & $\begin{array}{c}\text { Total carbohydrates } \\
(\mathrm{g} / 100 \mathrm{~g})\end{array}$ & $\begin{array}{c}\text { Caloric value } \\
(\mathrm{kcal} / 100 \mathrm{~g})\end{array}$ \\
\hline Human milk & & $1.45 \pm 0.01^{\mathrm{Ca}}$ & $3.05 \pm 0.21^{\mathrm{Ab}}$ & $0.25 \pm 0.02^{\mathrm{Ba}}$ & $7.21 \pm 0.31^{\mathrm{Ca}}$ & $62.09 \pm 3.17^{\mathrm{Ba}}$ \\
Stage 1 & C1 & $2.21 \pm 0.04^{\mathrm{B} 2}$ & $0.25 \pm 0.07^{\mathrm{B} 1}$ & $0.36 \pm 0.02^{\mathrm{B} 2}$ & $11.36 \pm 0.06^{\mathrm{B} 2}$ & $56.53 \pm 1.03^{\mathrm{C} 2}$ \\
& I1 & $0.58 \pm 0.02^{\mathrm{c}}$ & $4.60 \pm 0.14^{\mathrm{a}}$ & $0.11 \pm 0.01^{\mathrm{c}}$ & $2.66 \pm 0.23^{\mathrm{c}}$ & $54.36 \pm 2.26^{\mathrm{b}}$ \\
Stage 2 & C2 & $3.34 \pm 0.04^{\mathrm{A} 1}$ & $0.35 \pm 0.07^{\mathrm{B} 1}$ & $0.53 \pm 0.04^{\mathrm{A} 1}$ & $17.35 \pm 0.24^{\mathrm{A} 1}$ & $85.91 \pm 1.75^{\mathrm{A} 1}$ \\
& I2 & $1.00 \pm 0.01^{\mathrm{b}}$ & $0.25 \pm 0.07^{\mathrm{c}}$ & $0.18 \pm 0.02^{\mathrm{b}}$ & $4.98 \pm 0.18^{\mathrm{b}}$ & $26.17 \pm 1.39^{\mathrm{c}}$ \\
\hline
\end{tabular}

Results are expressed as mean \pm standard deviation, among three batches carried out in triplicate for each freeze concentration stage, with three repetitions for physicochemical composition. ${ }^{\mathrm{A}-\mathrm{C}}$ Within a column, different superscript uppercase letters denote significant differences $(P<0.05)$ between the human milk and the $C$ of each freeze concentration stage. ${ }^{\mathrm{a}-\mathrm{c}}$ Within a column, different superscript lowercase letters denote significant differences $(P<0.05)$ between the human milk and the I of each freeze concentration stage. ${ }^{1-2}$ Within a column, different superscript numbers denote significant differences $(P<0.05)$ between the $C$ of each freeze concentration stage.

In the present study, the small ice crystals produced by slow freezing contained less impurities and solids than those produced by a rapid freezing process. Therefore, the freezing generated a formation of regular crystals, which could account for the increase in $\mathrm{CF}$ and $\mathrm{PE}$, contributing to this concentration process. Moreover, Petzold et al. [35] affirmed that the concentration of the solution recovered by the freeze concentration process generally depends on the viscosity of the concentrate, which is directly related to the total solids and lipid contents. In the case of the human milk freeze concentration process, the fat retained in I1 (ice fraction of the first stage) (Table 2) influenced the lower value of PE $(P<0.05)$. It is noteworthy that the human milk was not skimmed, because this treatment is not applied by human milk banks, i.e., it is only submitted to the Holder pasteurization process (LTLT-low temperature long time). In short, the standardization technology provided for in the human milk processing and quality control manuals issued by Brazilian agencies does not allow the skimming of human Milk. Furthermore, contrary to standardization, the block freeze concentration performed in this study does not employ advanced equipment, which means it can be easily applied in human milk banks.

Aiming at validating the experimental results, a mass balance of both freeze concentration process stages was determined and compared to the theoretical values obtained. The mass balance was calculated for the total solids in milk, concentrates and ice fractions from each freeze concentration stage (Figure 4). These results confirm that the second freezing concentration stage showed the best performance, despite the retention of lipids observed in the ice fraction of the first stage (Table 2). Upon concentrating cheddar cheese whey, Aider, Halleux and Akbache [33] observed a drastic increase in the content of solids in the first two stages of concentration, obtaining values that reached $14.54 \%, 27.87 \%$, $30.17 \%$ and $34.20 \%$, respectively, in the four stages. Aider, Halleux and Melnikova [36] concentrated whole milk whey up to $37.7 \%$ of solids by gravitational thawing and $36.85 \%$ by using microwave-assisted thawing, also with a greater 


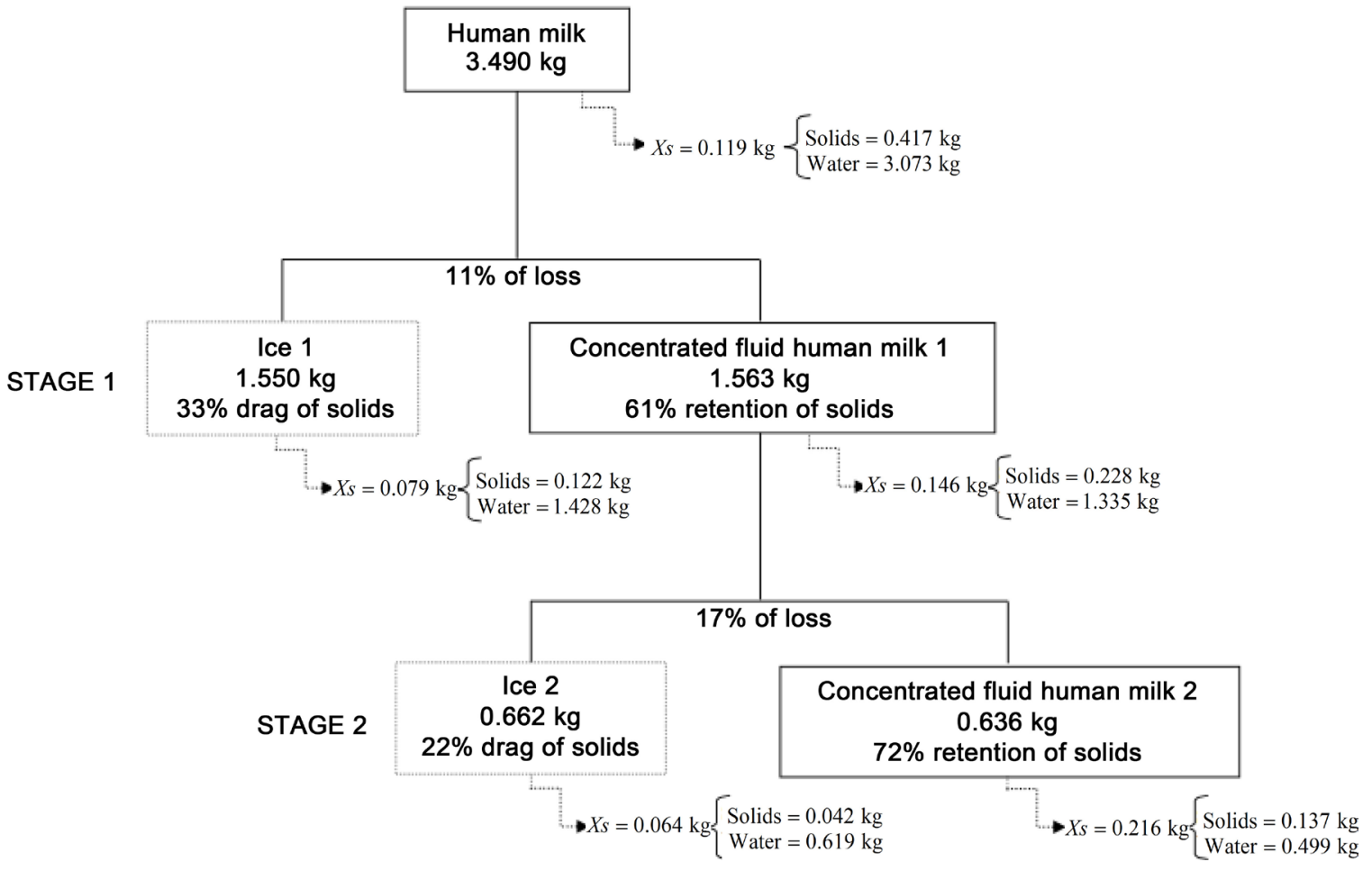

Figure 4. Human milk mass balance resulting from the block freeze concentration process.

process effectiveness in the first two stages. Such tendency was also observed in the freeze concentration of skimmed whey, reaching a value of approximately $35 \%$ in the fourth stage [37]. Upon concentrating skimmed milk, Aider and Ounis [26] obtained a concentrate with $43.72 \%$ in the fourth stage, also observing a decrease in the effectiveness of the process in the third and fourth stages. Even with the high effectiveness of the process that we ascertained in both stages of concentration used (Table 1), the values with respect to total solids were lower than the ones verified by Aider, Halleux and Akbache [33] in cheddar cheese whey.

It is noteworthy that concentration processes that use temperatures above $70^{\circ} \mathrm{C}$ may result in an irreversible aggregation of protein [26] [34] [36]. Because low temperatures are applied in the freeze concentration process, it seems to be a highly advantageous process that also enables the preservation of nutritive and biological components of foods [26] [37]. The values observed for the total protein, lipid, ash, carbohydrate contents and the calorific value of human milk, concentrates and ice phases resulting from both freeze concentration stages are shown in Table 2. The analysis of the data referring to the protein content shows that the concentration stage exerted a positive effect on the total protein content of human milk and on the concentrates $(P<0.05)$. The protein content decreased in I1, with a subsequent increase in I2, in the ice fraction. The same behavior was observed by Aider, Halleux and Melnikova [36] [38] and by Aider and Ounis [26] in the block freeze concentration of milk products, but only beginning at the third stage of concentration. It is known that human milk provides newborns with proteins whose quality is ideal for their nutrition [6] [11]. 
However, the enzymatic immaturity of preterm neonates makes them more prone to deficiencies or to toxicity deriving from any excess of amino acids than full-term neonates [39]. There is a decrease in protein contents in mature milk while the needs for proteins of preterm neonates remain high, resulting in the inappropriateness of that nutrient to supply such need. Supplementing human milk with protein is capable of correcting such deficiency [3] [40]. According to Corpeleijn et al. [41], the European Society for Paediatric Gastroenterology, Hepatology and Nutrition (ESPHGAN) recommends that the supply of proteins for newborns with less and more than $1 \mathrm{~kg}$ should be between 3.6 - 4.1 and 3.2 - 3.6 $\mathrm{g} / 100 \mathrm{~g}$, respectively. Thus, the addition of the $\mathrm{C} 2$ obtained in this study to the milk of donors could satisfy the recommendation of protein intake of preterm neonates.

The contents of lipids assessed in freeze concentration show that there was a difference $(P<0.05)$ between human milk and the concentrated and ice fractions. Nevertheless, the analysis of the data did not find any differences $(P<$ 0.05 ) between the concentrates and it was possible to verify that most of the lipid portion was retained in I1. Similar behavior was observed by Aider, Halleux and Melnikova [37] and Sánchez et al. [42]. The multiple functions exercised by lipids in infant feeding, such as a participation in the composition of cell membranes, myelin and prostaglandins, the delivery of vitamins and fat-soluble hormones, thermal isolation, energy deposit and assistance in the immunological protection of infants should be emphasized [43]. Moreover, they provide for around $50 \%$ of infant energy needs [44]. The need for essential fatty acids may result in immunological and neurological changes and alterations in growth and the skin, in addition to behavioral disorders [45]. Just as the content of protein present in the $\mathrm{C} 2$ sample, the lipids retained in I1 could also be used to increase the calorific value of human milk and could provide for the increase needs of energy of preterm neonates when necessary.

As in the study conducted by Aider, Halleux and Menilkova [38], the content of ashes in the $\mathrm{C} 2$ fraction was greater $(P<0.05)$ than the one found for $\mathrm{C} 1$ and that of human milk. Upon comparing the milk and the ice fractions, we noted that human milk presented greater ash content $(P<0.05)$ than I1 and I2. The values presented in this study for the ash contents of human mil are close to the ones observed by Silva et al. [44] for mature milk.

The carbohydrate contents of both concentrates increased with the freeze concentration process, being higher $(P<0.05)$ for $\mathrm{C} 2$. With respect to the ice fraction, we observed a reduction $(P<0.05)$ of the total carbohydrate contents in I1 and later increase $(P<0.05)$ in I2. Other studies [26] [36] [37] showed the same tendency in relation to the ice fraction, but beginning from the third stage of freeze concentration. Human milk carbohydrates are highly significant for newborns. Apart from providing energy, Moura [46] states that such carbohydrates help in the absorption of calcium and in the myelination of axons; hence, stimulating neurological development. The addition of the $\mathrm{C} 2$ obtained in this study to the milk of donors would satisfy the recommendations of ESPGHAN, 
referred by Corpeleijn et al. [41] with respect to the total carbohydrates recommended for preterm neonates, i.e., between 10.5 and $12.0 \mathrm{~g} / 100 \mathrm{~g}$.

Table 2 shows the results for protein, lipid and total carbohydrate contents for human milk, the concentrated and ice fractions. The $\mathrm{C} 2$ fraction showed a significantly higher $(P<0.05)$ caloric value than that of human milk or than any other fraction from the freeze concentration process. These results show de importance of the $\mathrm{C} 2$ fraction obtained. The caloric value observed for the ice fraction I1 is related to its high lipid retention.

It is a known fact that color is an important parameter influencing consumer choice, being also an indicative of quality [47], which can influence the acceptability of human milk. Sousa, Delgadillo and Saraiva [48] stated that when the milk is subjected to a different processing, it is expected that changes in color may occur. With respect to the $L^{\star}$ parameter (Table 3 ), when compared with human milk, it was possible to note its decrease and increase $(P<0.05)$ for concentrated fractions $(\mathrm{C} 2 ; \mathrm{C} 1)$ and ice fraction from the first stage of the freeze concentration process (I1), respectively. As the $L^{\star}$ parameter indicates lightness and the capacity of an object to either reflect or transmit light [49], this fact probably occurred due to the higher lipid concentration observed in the I1 sample. However, as cited by Verruck et al. [50] the smaller lightness also could be attributed to milk casein.

The results referring to the $a^{*}$ parameter indicate the tendency toward a green color in human milk, as well as in the concentrates and ice fractions. These results occurred due to the presence of riboflavin in the milk, as cited by Magenis et al. (2014). In relation to the $b^{\star}$ parameter the positive values of the samples were found for human milk and I1 fraction, while the other samples showed negative values. These positive and negative values indicate a tendency toward a yellow and blue color, which was also affected by lipid content (Table 2). These behaviors could be attributed to the presence or absence of carotenoids that have affinity by lipids. As cited before, all color parameters are closely linked to the quality aspects of human milk. However, the Hue $\left(h^{\star}\right)$ and Chroma $\left(C^{\star}\right)$ angles, being a function of $a^{*}$ and $b^{*}$, gives a more realistic perspective than a single

Table 3. Physical properties and color parameters $\left(L^{*}, a^{*}, b^{*}, C^{*}, h^{*}\right)$ of the human milk, concentrated fluid human milk $(C)$ and ice $(I)$ for the two freeze concentration stages.

\begin{tabular}{|c|c|c|c|c|c|c|c|c|}
\hline & & Density $\left(\mathrm{g} / \mathrm{cm}^{3}\right)$ & Viscosity (mPa.s) & $L^{*}$ & $a^{*}$ & $b^{*}$ & $C^{*}$ & $h^{*}$ \\
\hline Human milk & & $1.03 \pm 0.01^{\mathrm{Ba}}$ & $12.14 \pm 0.26^{\mathrm{Ba}}$ & $60.12 \pm 0.64^{\mathrm{Ab}}$ & $-2.58 \pm 0.05^{\mathrm{BC}}$ & $4.01 \pm 0.80^{\mathrm{Ab}}$ & $4.78 \pm 0.66^{\mathrm{Bb}}$ & $125.60 \pm 3.10^{\mathrm{Cb}}$ \\
\hline \multirow[t]{2}{*}{ Stage 1} & $\mathrm{C} 1$ & $1.07 \pm 0.01^{\mathrm{A} 1}$ & $13.09 \pm 0.06^{\mathrm{B} 2}$ & $43.77 \pm 0.30^{\mathrm{C} 2}$ & $-1.97 \pm 0.01^{\mathrm{Al}}$ & $-5.28 \pm 0.08^{\mathrm{C} 2}$ & $5.64 \pm 0.07^{\mathrm{A} 1}$ & $249.50 \pm 0.30^{\mathrm{Al}}$ \\
\hline & I1 & $1.03 \pm 0.01^{\mathrm{a}}$ & $9.81 \pm 0.38^{\mathrm{b}}$ & $65.15 \pm 0.42^{\mathrm{a}}$ & $-2.44 \pm 0.03^{\mathrm{b}}$ & $6.91 \pm 0.56^{\mathrm{a}}$ & $7.33 \pm 0.54^{\mathrm{a}}$ & $109.50 \pm 1.20^{c}$ \\
\hline \multirow[t]{2}{*}{ Stage 2} & $\mathrm{C} 2$ & $1.09 \pm 0.01^{\mathrm{A} 1}$ & $20.82 \pm 0.79^{\mathrm{Al}}$ & $57.34 \pm 0.55^{\mathrm{B} 1}$ & $-2.82 \pm 0.05^{\mathrm{C} 2}$ & $-0.58 \pm 0.23^{\mathrm{B} 1}$ & $2.89 \pm 0.09^{\mathrm{C} 2}$ & $189.50 \pm 2.30^{\mathrm{B} 2}$ \\
\hline & $\mathrm{I} 2$ & $1.02 \pm 0.01^{\mathrm{a}}$ & $8.15 \pm 0.07^{c}$ & $39.35 \pm 0.10^{c}$ & $-0.23 \pm 0.04^{\mathrm{a}}$ & $-2.07 \pm 0.19^{c}$ & $2.08 \pm 0.19^{c}$ & $263.60 \pm 0.60^{\mathrm{a}}$ \\
\hline
\end{tabular}

Results are expressed as mean \pm standard deviation, among three batches carried out in triplicate for each freeze concentration stage, with three repetitions for density and viscosity; and five repetitions for the color parameters. ${ }^{\mathrm{A}-\mathrm{C}} \mathrm{Within}$ a column, different superscript uppercase letters denote significant differences $(P<0.05)$ between the human milk and the $\mathrm{C}$ of each freeze concentration stage. ${ }^{\mathrm{a}-\mathrm{c}}$ Within a column, different superscript lowercase letters denote significant differences $(P<0.05)$ between the human milk and the $I$ of each freeze concentration stage. ${ }^{1-2}$ Within a column, different superscript numbers denote significant differences $(P<0.05)$ between the $\mathrm{C}$ of each freeze concentration stage. 
color. The Hue angle indicates visual assessment of food discoloration, while the Chroma represents its color saturation. Therefore, the results obtained for $h^{\star}$ indicated that all fractions obtained during the freeze concentration process were affected (Table 3), where the sample with the more and less pronounced tonality is represented by the fractions I1 and I2, respectively, but none was equal $(P<$ $0.05)$ to the human milk. The $C^{*}$ results indicated that the greater color saturations were observed for the $\mathrm{C} 1$ and $\mathrm{I} 1$ samples and this fact could be credited to the greater protein (casein) and lipid contents (Table 2) present, respectively.

Other important physical parameters for the human milk are the density and the viscosity. Sousa and Silva [51] and Aider and Ounis [26] affirmed that the density and the viscosity, respectively, could be related to the total solid content of raw material. Moukarzel and Bode [52] highlighted that although much attention is often given to the composition and caloric value of human milk, density and viscosity are essential for pre-term infant feeding.

It was observed (Table 3$)$ for the density value a slight increase $(P<0.05)$ in the concentrated, while for ices fractions no differences $(P>0.05)$ were verified, when compared with the human milk. According to Oliveira et al. [4] supplements with density values close to those of the human milk are desirable for pre-term infants. These authors stated that low density values contribute for gastric stabilization, thus human milk could be a protective mechanism favoring emptying and compensating the immature gastric motility in preterm newborns. Despite C2 shows the highest $(P<0.05)$ viscosity result (Table 3$)$, it should be noted that it is composed by human milk. Normally, a problem with supplements with high viscosity values is related to the sensitivity of newborns to cow's milk. Corvaglia et al. [53] highlighted that cow's milk induces gastric dysrhythmia, which can lead to a severe impairment of gastric motor function and also to an exacerbation of gastro-esophageal reflux, and delayed gastric emptying. Therefore, the higher C2 viscosity obtained in this study does not represent a negative factor, since such concentrate would not be directly supplied to preterm infants, but would be added to the milk of donors when necessary.

Our results reinforce the need for carefully controlling and optimizing all of the steps in human milk processing, in order to explore alternative treatments for human milk concentration, using its fractions for replacing preterm baby supplements that frequently contain proteins from cow's milk. So, our results support early initiation of human milk fortification to increase protein, lipid and caloric intake by newborns. Finally, in the future, this work could contribute to the implementation of this efficient technology at human milk banks and might help reduce term and preterm infant morbidity and mortality, allowing infants to achieve their full potential for growth and development.

\section{Conclusions}

The results obtained in this study showed that the block freeze concentration process can be applicable to the concentration of human milk. The concentrate from stage 2 and the ice fraction from first concentration stage show potential to 
be used as protein and lipid human milk fortifier, respectively. Therefore, both fractions could improve the weight gain and growing of premature infants.

Finally, this process showed to be safe to freeze concentrate human milk and, because it is a simple and inexpensive method, it can be employed at any Human Milk Bank.

\section{References}

[1] Ahrabi, A.F. and Schanler, R.J. (2013) Human Milk Is the Only Milk for Premies in the NICU! Early Human Development, 89, S51-S53.

[2] Halleux, V., Pieltain, C., Senterre, T. and Rigo, J. (2017) Review. Use of Donor Milk in the Intensive Care Unit. Seminars in Fetal and Neonatal Medicine, 22, 23-29.

[3] Underwood, M.A. (2013) Human Milk for the Premature Infant. Pediatric Clinics of North America, 60, 189-207.

[4] Oliveira, S.C., Bourlieu, C., Ménard, O., Bellanger, A., Henry, G., Rousseau, F., Dirson, E., Carrièrre, F., Dupont, D. and Deglaire, A. (2016) Impact of Pasteurization of Human Milk on Preterm Newborn in Vitro Digestion: Gastrointestinal Disintegration, Lipolysis and Proteolysis. Food Chemistry, 211, 171-179.

[5] Grance, T.R.S., Serafin, P.O., Thomaz, D.M.C. and Palhares, D.B. (2015) Homologous Fortifier for Very Low Birth Weight Preterm Infant Feed. Revista Paulista de Pediatria, 33, 28-33.

[6] Lönnerdal, B. (2017) Bioactive Proteins in Human Milk-Potential Benefits for Preterm Infants. Clinics in Perinatology, 44, 179-191.

[7] Errázuriz, G., Lucero, Y., Ceresa, S., Gonzalez, M., Rossel, M. and Vivies, A. (2016) Clinical Characteristics and Management of Infants Less than 1-Year-Old Suspected with Allergy to Cow's Milk Protein. Revista Chilena de Pediatría, 87, 449-454.

[8] Cristofalo, E.A., Schanler, R.J., Blanco, C.L., Sullivan, S., Trawoeger, R., KiechlKohlendorfer, U., Dudell, G., Rechtman, D.J., Lee, M.L., Lucas, A. and Abrams, S. (2013) Randomized Trial of Exclusive Human Milk versus Preterm Formula Diets in Extremely Premature Infants. The Journal of Pediatrics, 163, 1592-1595.

[9] Schanler, R.J. (2015) In Time: Human Milk Is the Feeding Strategy to Prevent Necrotizing Enterocolitis. Revista Paulista de Pediatria, 33, 131-133.

[10] Sullivan, S., Richard, J., Schanler, R.J., Kim, J.H., Patel, A.L., Trawöger, R., KiechlKohlendorfer, U., Chan, G.M., Blanco, C.L., Abrams, S., Cotten, M., Laroia, N., Ehrenkranz, R.A., Dudell, G., Cristofalo, E.A., Meier, P., Lee, M.L., Rechtman, D.J. and Lucas, A. (2010) An Exclusively Human Milk-Based Diet Is Associated with a Lower Rate of Necrotizing Enterocolitis than a Diet of Human Milk and Bovine Milk-Based Products. The Journal of Pediatrics, 156, 562-567.

[11] Thomaz, D.M.C., Serafim, P.O., Durval, B., Palhares, D.B., Melnikov, P., Venhofen, L. and Vargas, M.O.F. (2012) Comparison between Homologous Human Milk Supplements and a Commercial Supplement for Very Low Birth Weight Infants. Journal de Pediatria, 88, 119-124.

[12] Santos, M.M., Martinez, F.E., Sieber, V.M., Pinhata, M.M.M. and Felin, M.L.S. (1997) Acceptability and Growth of VLBW-Infants Fed with Own Mother's Milk Enriched with a Natural or Commercial Human Milk Fortifier (HMF) 1370. Pediatric Research, 41, 231. https://doi.org/10.1203/00006450-199704001-01389

[13] Su, M.-Y., Broadhurst, M., Liu, C.-P., Gathercole, J.G., Cheng, W.-L., Qi, X.-Y., Clerens, S., Dyer, J.M., Day, L. and Haigh, B. (2017) Comparative Analysis of Human Milk and Infant Formula Derived Peptides Following in Vitro Digestion. Food Chemistry, 221, 1895-1903. 
[14] Belén, F., Sánchez, J., Hernández, E., Auleda, J.M. and Raventós, M. (2012) One Option for the Management of Wastewater from Tofu Production: Freeze Concentration in a Falling-Film System. Journal of Food Engineering, 110, 364-373.

[15] Sánchez, J., Ruiz, Y., Auleda, J.M., Hernández, E. and Raventós, M. (2009) Review. Freeze Concentration in the Fruit Juices Industry. Food Science and Technology International, 15, 303-315. https://doi.org/10.1177/1082013209344267

[16] Yee, P.L., Wakisaka, M., Shirai, Y. and Hassan, M.A. (2003) Effects of Single Food Components on Freeze Concentration by Freezing and Thawing Technique. Japan Journal of Food Engineering, 4, 77-83.

[17] Aider, M. and Halleux, D. (2009) Review. Cryoconcentration Technology in the Bio-Food Industry: Principles and Applications. LWT-Food Science and Technology, 42, 679-685.

[18] Yee, K.W.K., Wiley, D.E. and Bao, J. (2007) Whey Protein Concentrate Production by Continuous Ultrafiltration: Operability under Constant Operating Conditions. Journal of Membrane Science, 290, 125-137.

[19] Sánchez, J., Ruiz, Y., Raventós, M., Auleda, J.M. and Hernández, E. (2010) Progressive Freeze Concentration of Orange Juice in a Pilot Plant Falling Film. Innovative Food Science and Emerging Technologies, 11, 644-651.

[20] Auleda, J.M., Raventós, M., Sánchez, J. and Hernández, E. (2011) Estimation of the Freezing Point of Concentrated Fruit Juices for Application in Freeze Concentration. Journal of Food Engineering, 105, 289-294.

[21] Chabarov, A. and Aider, M. (2014) Mathematical Modeling and Experimental Validation of the Mass Transfer During Unidirectional Progressive Cryoconcentration of Skim Milk. Innovative Food Science and Emerging Technologies, 21, 151-159.

[22] ANVISA (2008) Brazilian National Health Surveillance Agency. Human Milk Bank: Operation, Prevention and Control of Risks. ANVISA, Brasília.

[23] Boaventura, B.C.B., Murakami, A.N.N, Prudêncio, E.S., Maraschin, M., Murakami, F.S., Amante, E.R. and Castanho, R.D.M. (2013) Enhancement of Bioactive Compounds Content and Antioxidant Activity of Aqueous Extract of Mate (Ilex paraguariensis A. St. Hil.) through Freeze Concentration Technology. Food Research International, 53, 686-692.

[24] Instituto Adolfo Lutz (2008) Analytical Standards of the Adolfo Lutz Institute: Physicochemical Methods for Food Analysis. IAL, São Paulo.

[25] AOAC (2005) Official Methods of Analysis of the Association Analytical Chemists. 18th Edition, Association of Official Analytical Chemists, Rockville.

[26] Aider, M. and Ounis, W.B. (2012) Skim Milk Cryoconcentration as Affected by the Thawing Mode: Gravitational vs. Microwave-Assisted. International Journal of Food Science and Technology, 47, 195-202. https://doi.org/10.1111/j.1365-2621.2011.02826.x

[27] Bélen, F., Benedetti, S., Sánchez, J., Hernández, E., Auleda, J.M., Prudêncio, E.S., Petrus, J.C.C. and Raventós, M. (2013) Behavior of Functional Compounds during Freeze Concentration of Tofu Whey. Journal of Food Engineering, 116, 681-688.

[28] Orellana, P., Cerda, M. and Parra (2016) Vacuum-Assisted Block Freeze Concentration Applied to Wine. Innovative Food Science and Emerging Technologies, 36, 330-335.

[29] Masoud, W. and Jakobsen, M. (2003) Surface Ripened Cheeses: The Effects of Debaryomyces hansenii, $\mathrm{NaCl}$ and $\mathrm{pH}$ on the Intensity of Pigmentation Produced by Brevibacterium linens and Corynebacterium flavescens. International Dairy Journal, 13, 231-237. 
[30] Palczewska-Tulinska and Oracz, P.J. (2005) Selected Physicochemical Properties of Hexamethylcyclotrisiloxane, Octamethylcyclotetrasiloxane, and Decamethylcyclopentasiloxane. Journal of Chemical \& Engineering Data, 50, 1711-1719. https://doi.org/10.1021/je050173+

[31] Pereira, C.I.V., Dametto, J.F.S. and Oliveira, J.C.C. (2016) Evaluation of Human Milk Titratable Acidity before and after Addition of a Nutritional Supplement for Preterm Newborns. Journal de Pediatria, 92, 499-504.

[32] Cavalcante, J.L.P., Telles, F.J.S., Peixoto, M.M.L.V. and Rodrigues, R.C.B. (2005) Use of the Titratable Acidity in the Quality Control of the Milked Human Milk. Ciência e Tecnologia de Alimentos, 25,103-108. https://doi.org/10.1590/S0101-20612005000100017

[33] Aider, M., Halleux, D. and Akbache, A. (2007) Whey Cryoconcentration and Impact on Its Composition. Journal of Food Engineering, 82, 92-102.

[34] Sánchez, J., Hernández, E., Auleda, J.M. and Raventós, M. (2011) Freeze Concentration of Whey in a Falling-Film Based Pilot Plant: Process and Characterization. Journal of Food Engineering, 103, 147-155.

[35] Petzold, G., Moreno, J., Lastra, P., Rojas, K. and Orellana, P. (2015) Block Freeze Concentration Assisted by Centrifugation Applied to Blueberry and Pineapple Juices. Innovative Food Science Emerging Technologies, 30, 192-197.

[36] Aider, M., Halleux, D. and Melnikova, I. (2008) Gravitational and Microwave-Assisted Thawing During Milk Whey Cryoconcentration. Journal of Food Engineering, 88, 373-380.

[37] Aider, M., Halleux, D. and Melnikova, I. (2009) Skim Milk Whey Cryoconcentration and Impact on the Composition of the Concentrated and Ice Fractions. Food Bioprocess Technology, 2, 80-88. https://doi.org/10.1007/s11947-007-0023-0

[38] Aider, M., Halleux, D. and Melnikova, I. (2009) Skim Acidic Milk Whey Cryoconcentration and Assessment of Its Functional Properties: Impact of Processing Conditions. Innovative Food Science and Emerging Technologies, 10, 334-341.

[39] Santos, S.C., Figueiredo, C.M., Andrade, S.M.O. and Palhares, D.B. (2007) Plasma Amino Acids in Preterm Infants Fed Different Human Milk Diets from a Human Milk Bank. European e-Journal of Clinical Nutrition and Metabolism, 2, 51-56.

[40] Heiman, H. and Schanler, R.J. (2006) Benefits of Maternal and Donor Human Milk for Premature Infants. Early Human Development, 82, 781-787.

[41] Corpeleijn, W.E., Vermeulen, M.J., van den Akker, C.H. and van Goudoeve, J.B. (2011) Feeding Very-Low-Birth-Weight Infants: Our Aspirations versus the Reality in Practice. Annals of Nutrition and Metabolism, 58, S20-S29. https://doi.org/10.1159/000323384

[42] Sánchez, J., Hernández, E., Auleda, J.M. and Raventós, M. (2011) Review: Freeze Concentration Technology Applied to Dairy Products. Food Science and Technology International, 17, 5-9.

[43] Laurindo, V.M., Calil, T., Leone, C.R. and Ramos, J.L.A. (1991) Nutritional Composition of Colostrum of Mothers of Suitable and Small Term Infants for Gestational Age. III-Conditions That Alter the Nutritional Composition of Human Milk. Pediatria São Paulo. http://www.pediatriasaopaulo.usp.br/upload/pdf/83.pdf

[44] Silva, R.C., Escobedo, J.P., Gioielli, L.A., Quintal, V.S., Ibidi, S.M. and Albuquerque, E.M. (2007) Centesimal Composition of Human Milk and Physico-Chemical Properties of Its Fat. Química Nova, 30, 1535-1538.

[45] Tinoco, S.M.B., Sichieri, R., Setta, C.L., Moura, A.S., Santos, F.S. and Do Carmo, M.G.T. (2008) Trans Fatty Acids from Milk of Brazilian Mothers of Premature In- 
fants. Journal of Paedriatics and Child Health, 44, 50-56.

[46] Moura, E.C. (2005) Nutrição. In: Carvalho, M.R. and Tamez, R.N., Eds., Breastfeeding: Scientific Bases, Guanabara Koogan, Rio de Janeiro, 26-56.

[47] Nascimento, C.F., Santos, P.M., Pereira-Filho, E.R. and Rocha, F.R.P. (2017) Recent Advances on Determination of Milk Adulterants. Food Chemistry, 221, 1232-1244.

[48] Sousa, S.G., Delgadillo, I. and Saraiva, J.A. (2016) Human Milk Composition and Preservation: Evaluation of High-Pressure Processing as a Non-Thermal Pasteurization Technology. Critical Reviews in Food Science and Nutrition, 56, 1043-1060. https://doi.org/10.1080/10408398.2012.753402

[49] Magenis, R.B., Prudêncio, E.S., Fritzen-Freire, C.B., Stephan, M.P., Egito, A.S. and Daguer, H. (2014) Rheological, Physicochemical and Authenticity Assessment of Minas Frescal Cheese. Food Control, 45, 22-28.

[50] Verruck, S., Prudêncio, E.S., Müller, C.M.O., Fritzen-Freire, C.B. and Amboni, R.D.M.C. (2015) Influence of Bifidobacterium Bb-12 on the Physicochemical and Rheological Properties of Buffalo Minas Frescal Cheese During Cold Storage. Journal of Food Engineering, 151, 34-42.

[51] Sousa, P.P.R. and Silva, J.A. (2010) Quality Monitoring of Human Milk Milked and Distributed in Reference Milk Bank. Revista do Instituto Adolfo Lutz, 69, 7-14.

[52] Moukarzel, S. and Bode, L. (2017) Human Milk Oligosaccharides and the Preterm Infant: A Journey in Sickness and in Health. Clinics in Perinatology, 44, 193-207.

[53] Corvaglia, L., Martini, S. and Faldella, G. (2013) Gastro-Oesophageal Reflux: Pathogenesis, Symptoms, Diagnostic and Therapeutic Management. Early Human Development, 89S4, S18-S19.

\section{Submit or recommend next manuscript to SCIRP and we will provide best service for you:}

Accepting pre-submission inquiries through Email, Facebook, LinkedIn, Twitter, etc. A wide selection of journals (inclusive of 9 subjects, more than 200 journals)

Providing 24-hour high-quality service

User-friendly online submission system

Fair and swift peer-review system

Efficient typesetting and proofreading procedure

Display of the result of downloads and visits, as well as the number of cited articles

Maximum dissemination of your research work

Submit your manuscript at: http://papersubmission.scirp.org/

Or contact fns@scirp.org 